\title{
The Challenges of Archaeological Reconstruction: Back Then, Now and Tomorrow
}

\author{
Sebastian Hageneuer \\ University of Cologne
}

\begin{abstract}
Archaeological reconstruction has been part of archaeology since its beginnings. From rudimental sketches to elaborated artwork, from pages in a notebook to immersive three-dimensional worlds, from detailed scientific research to mere fantasy, the spectrum of quality, media and reliability of archaeological reconstructions is broad and shows a wide variety. In most cases, however, we are not able to see that variety in the visualisation itself and are misled in believing what the past looked like. Reconstructions are a popular way of communicating the past to a broader audience, as can be observed in museums, magazines, documentaries or even video games. The effect of an elaborated reconstruction is however often preferred over the truthfulness of the underlying sources. Although there are guidelines and charters promoting a good way of documenting and presenting, they are often ignored. This chapter aims to sum up the development of reconstructions from the very beginning to today and give a glimpse into the future.
\end{abstract}

How to cite this book chapter:

Hageneuer, S. 2020. The Challenges of Archaeological Reconstruction: Back Then, Now and Tomorrow. In: Hageneuer, S. (ed.) Communicating the Past in the Digital Age: Proceedings of the International Conference on Digital Methods in Teaching and Learning in Archaeology (12-13 October 2018). Pp. 101-112. London: Ubiquity Press. DOI: https://doi.org/10.5334/bch.h. License: CC-BY 4.0 


\section{Keywords}

Reconstruction, Museum, Communication, Documentation, Heritage

\section{Introduction}

In 1717, William Stuckeley, British antiquarian and member of the Royal Society, said: 'Without drawing or designing the Study of Antiquities or any other Science is lame and imperfect' (Piggott 1978: 7). Since its beginnings, archaeology has always been accompanied by visual media, and rightly so. Visual media help to convey information non-verbally and at a glance, whether plans, sections, photos, sketches or - for the purpose of this chapter reconstructions. Reconstructions try to re-visualise artefacts, a landscape or architecture, which does not exist anymore. The latter in particular are often used within archaeology, a good example being images by Jean-Claude Golvin, as they show the different ways in which reimagination of the ancient past can take place (Golvin 2019). Although often described as such, visual representations of reconstructions are far more then pretty pictures.

Reconstructions grab the attention of the viewer, as visual media do in general. Well-made visualisations have the power to convey authenticity (Bahrani 2001: 16), which makes them credible to a point that we even today turn back to them as a valid reference of the past (Micale 2010). In this respect, they can be a dangerous source of misinformation, if communicated wrongly. The question therefore remains: what can we actually learn from reconstructions? We also need to ask ourselves how much of the reconstructions we can believe (Simon 1997: 25). As they are always influenced by the state of knowledge as well as assumptions and agendas, we can be sure at least that they will tell us something about the time they were created: 'Such reconstructions are fantasies that tell us more about the period of reconstruction than about the ancient past' (Bahrani 2001: 17).

However, as they do inform us about the state of our knowledge, reconstruction drawings can function as a kind of visualised theory (Bator, van Ess \& Hageneuer 2013; Hageneuer 2014), helping as a reference for argumentation to be discussed like any other scientific paper. The question remains whether they are also suitable for conveying information in a museum setting. In the field of a museum exhibition, in particular, reconstruction images or animations are often used to convey information about the past. In this regard, I have pointed to the danger of blindly accepting reconstructions as such (Hageneuer 2016a) and offered possibilities to counter that problem (Hageneuer 2016b; Franzmeier \& Hageneuer 2017). In this chapter, however, I want to submit a very condensed overview of reconstruction drawings in the museum with one example from the past, one from today and a glimpse into the future. In this 
way, I hope to showcase what we can learn from the past and what we need to improve for the future. My examples will focus on the region of the Near East and Egypt, although this overview could be done for any other archaeological discipline as well.

\section{Reconstructions of and from the past}

As mentioned before, reconstructions in archaeology are as old as the discipline itself. Since its beginnings, archaeologists have used reconstruction drawings to illustrate their findings and interpretations. As an example, I want to take a closer look at one of the first archaeological reconstruction drawings of the ancient Near East. Sir Austen Henry Layard (1817-1894) was on his way from London to Ceylon (modern-day Sri Lanka) to become a lawyer, but lost interest in this during his travels through Mesopotamia. After abandoning his plans to go to Ceylon, he quickly became the assistant to Sir Stratford Canning, the British ambassador in Constantinople, for whom he started the excavations in Nimrud, near modern-day Mosul in Iraq. Finding the remains of two Neo-Assyrian palaces on his first day (Larsen 2010: 101103), his work lasted from 1845 to 1847 and in a second campaign from 1849 to 1851 he also excavated Tell Kuyunjik (ancient Nineveh). He published his results in different editions but mainly in the form of widely available travelogues (for example Layard 1849a; 1853a) or expensive large folio publications intended for a more scientific audience (Layard 1849b; 1853b). In his 1853 large folio publication A Second Series of the Monuments of Nineveh, the first plate consisted of a reconstruction drawing of the western side of the palaces of Nimrud (Figure 1).

In the scope of this chapter, I do not want to discuss the contents of the drawing (Layard 1853b: 1), the scientific value of the reconstruction itself (Reade 2008) or even the Orientalist message behind it (Bahrani 2001), but rather its popularisation and distribution. Layard's publication was what we would call today a limited edition, with only a couple of hundred copies distributed anywhere in the world. By that time, however, Layard and his excavations were what everyone was talking about. His popularity combined with a good sense of public engagement made sure his (and James Fergusson's) thoughts about the visual representation of ancient Assyria remained popular. Today, the image is still frequently used as a cover image for various scientific and non-scientific publications worldwide (for example, Parpola \& Whiting 1997; Adkins 2003; Faiella 2006; Der Spiegel 2016), which should not be surprising considering its artistic beauty.

Zainab Bahrani correctly points to the problem of the general authority in elaborate reconstruction drawings (Bahrani 2001: 16), a problem that is also discussed with the newer medium of 3D models today (Buccellati 2015; 


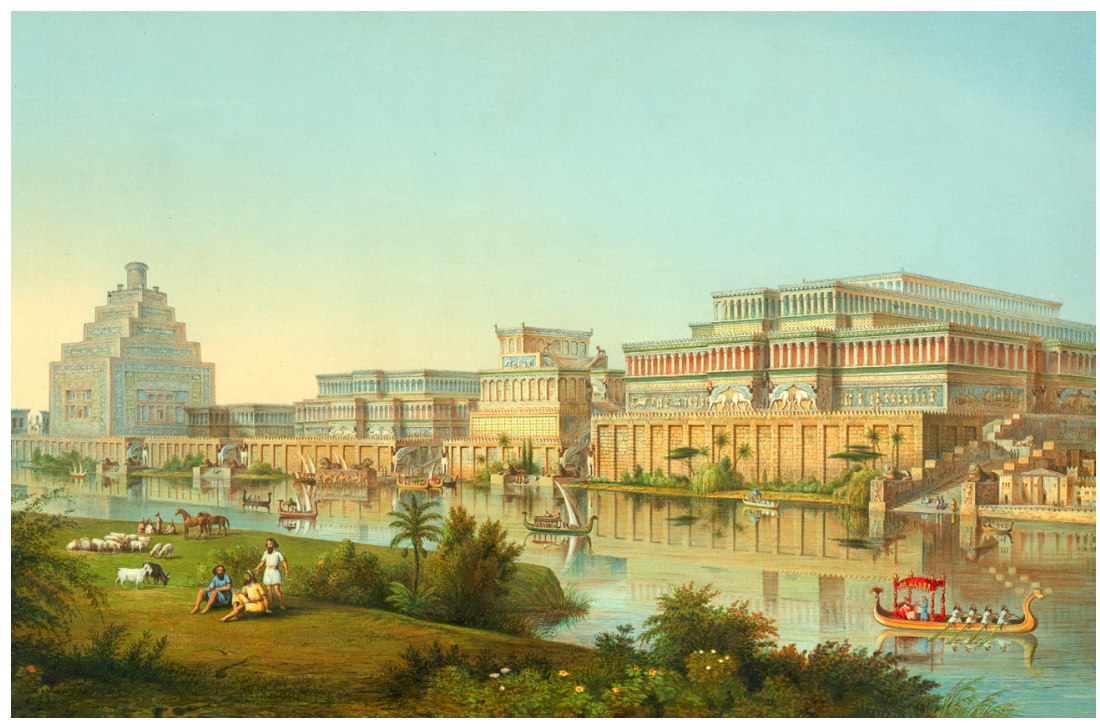

Figure 1: A proposal of the western side of the palaces of Nimrud. Drawn by Thomas Mann Baynes under instructions of James Fergusson for Sir Austen Henry Layard, published in 1853.

Lanjouw 2016: 3-4). With the older medium of drawings, however, we already can see the longevity of beautiful reconstructions, despite their problems. In a recent exhibition at the British Museum in London ('I am Ashurbanipal, king of the world, king of Assyria', 8 November 2018-24 February 2019), Layard's reconstruction was used in its promotional video ${ }^{1}$ as the basis for a threedimensional reconstruction of a city during the narrative of the clip. Besides the already-mentioned archaeological problems with this reconstruction and the widely known discussion around it, the creators of the video failed to mention that Ashurbanipal's palace was located in Nineveh and not in Nimrud, as suggested by the reconstruction. Nevertheless, as this image is one of the more elaborate ones depicting the Neo-Assyrian Empire, it never lost its authority, even to scholars of ancient Near Eastern archaeology.

I am no exception and use the reconstruction frequently in class or in articles (for example Hageneuer 2016c; 2019) to show an example of one of the first reconstruction drawings made. Nevertheless, I believe it is important to highlight the problematic parts of the image or (like in this chapter) its discourse. The communication of these images needs to reflect our current understanding of it.

${ }^{1}$ [online] YouTube. Available at: https://youtu.be/0OZe-y5tk9Q [Accessed 13 May 2019]. 


\section{Reconstructions today}

We should expect that reconstructions made today are more thoroughly researched and better communicated than in the past, but, as the example of the British Museum has shown, this often is not the case. Of course, we have to differentiate commercial from scientific work, but (1) these categories do not need to be mutually exclusive and (2) both should live up to a certain standard.

As an example of a reconstruction made in the last few years ('the present'), I want to discuss a reconstruction made by myself in 2016. Up to that point, I was a freelancer specialising in creating 3D reconstructions for archaeological projects from around the world. Similar to the reconstruction before, this also shows a whole complex of buildings, in fact a whole city (Figure 2). The city of Pi-Ramesse ('House of Ramesses') was founded by King Ramesses II at the beginning of his 67-year reign in the early 13th century BCE in the northeastern Nile Delta, about 120 kilometres north-east of modern Cairo. ${ }^{2}$ Between 17 December 2016 and 18 June 2017 the Badisches Landesmuseum Karlsruhe hosted an exhibition called 'Ramesses - Divine Ruler of the Nile.' Beside Ramesses himself and his life, one part of the exhibition was dedicated to his capital city. In an animation (Artefacts 2016), I was assigned to give an insight into the results of over 35 years of excavation and the daily life in Pi-Ramesse in under seven minutes.

I do not want to get into either the details of the content (Franzmeier \& Hageneuer 2017: 23) or the popularisation or distribution (which we cannot analyse at this point). Instead, in continuation of the argument before, I want to talk about the communication of archaeological knowledge. In order to do so, I would like to start with an insight into the communication process with the client, which in this case was the Badisches Landesmuseum Karlsruhe (as host of the exhibition), the Roemer- und Pelizaeus Museum in Hildesheim (as the current partner of the excavation) and the excavation project itself (providing the necessary data). All three partners (and I) were excited about creating a 3D visualisation of the ancient capital of Ramesses II, although everyone had individual expectations. For the museum partners, a visually pleasing result with animated flyovers of the reconstructed city were important. Also, the animation should not be too long, as visitors needed to pass by constantly. The excavation project on the other hand was more focused on presenting as much data as possible and showcasing the newest and best results. Also, a potential continuation of the created 3D model was intended or at least wished for. I, as the

${ }^{2}$ For more information see: Franzmeier and Pusch 2016; Franzmeier and Hageneuer 2017; Hageneuer 2016b; Pusch and Herold 2001.

${ }^{3}$ For more information about the exhibition see: [online] Landesmuseum Karlsruhe. Available at: https://www.landesmuseum.de/website/Deutsch/Sonderausstellungen/Rueckblick/2017/Ramses.htm [Accessed 16 May 2019]. 


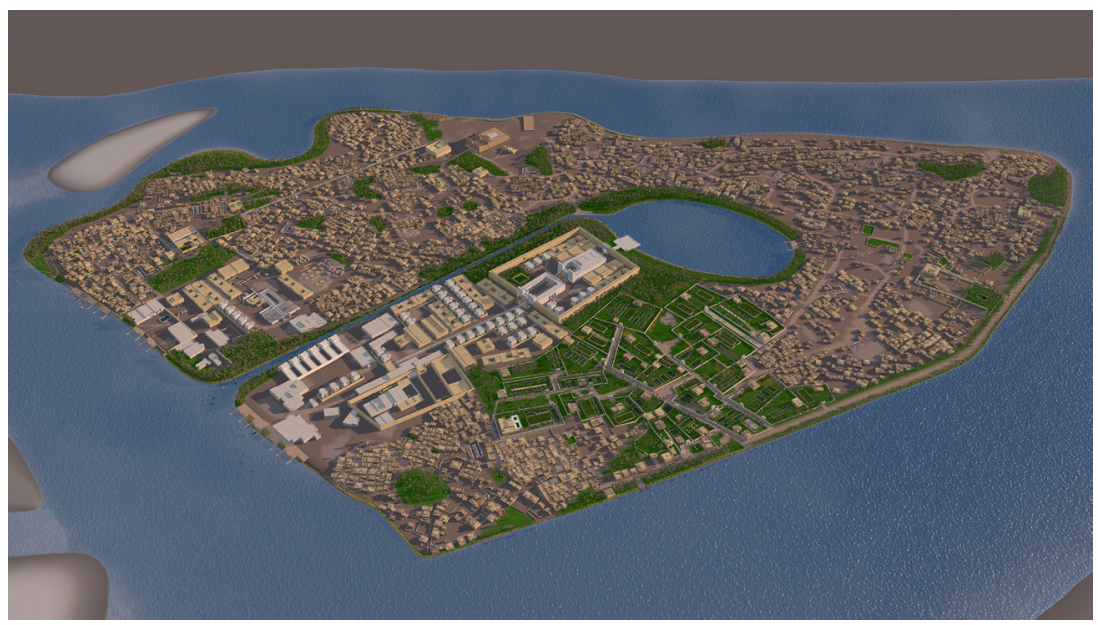

Figure 2: Reconstruction of the city of Pi-Ramesse in the early 13th century BCE, 2016. (C) artefacts-berlin.de.

contractor, was concerned with the timeline and amount of work (in relation to the compensation), as the opening of the exhibition was only nine months away. We therefore had to find a way to create and document the animation rather quickly in order to be able to communicate it properly for a broader as well as scientific audience.

The reconstruction process was a mixture of different methods. Where the excavations had produced sufficient results, the reconstruction was based upon these results and intense discussions with Edgar B. Pusch, the former excavator and walking encyclopaedia of information about the site. Former reconstruction attempts were available and incorporated whenever possible and the whole discussion and all decisions, mostly done via e-mail, were archived for later publication. One example of a more detailed reconstruction can be seen with the royal stables near the end of the animation (Artefacts 2016: 4:10-6:19). Where there was no excavation but geomagnetic prospection, the reconstruction process relied heavily on other sites, for example where private houses had already been found and reconstructed (e.g. Endruweit 1994; Aufrère, Golvin \& Goyon 1991-1997; Tietze 2008). These were recreated in close discussion with the head of the excavation project in Pi-Ramesse, Henning Franzmeier, and put accordingly on the outlines provided by the geomagnetic prospection plan. For the third area, the area neither excavated nor surveyed and mostly built over by the modern-day village of Qantir, another approach was necessary. By analysing the already-reconstructed parts of the city based on the excavation and geomagnetic prospection, we jointly discussed possible ways of filling the gaps, by copying existing reconstructions and creating new ones based on assumptions of architecture that was not found but was most probably 


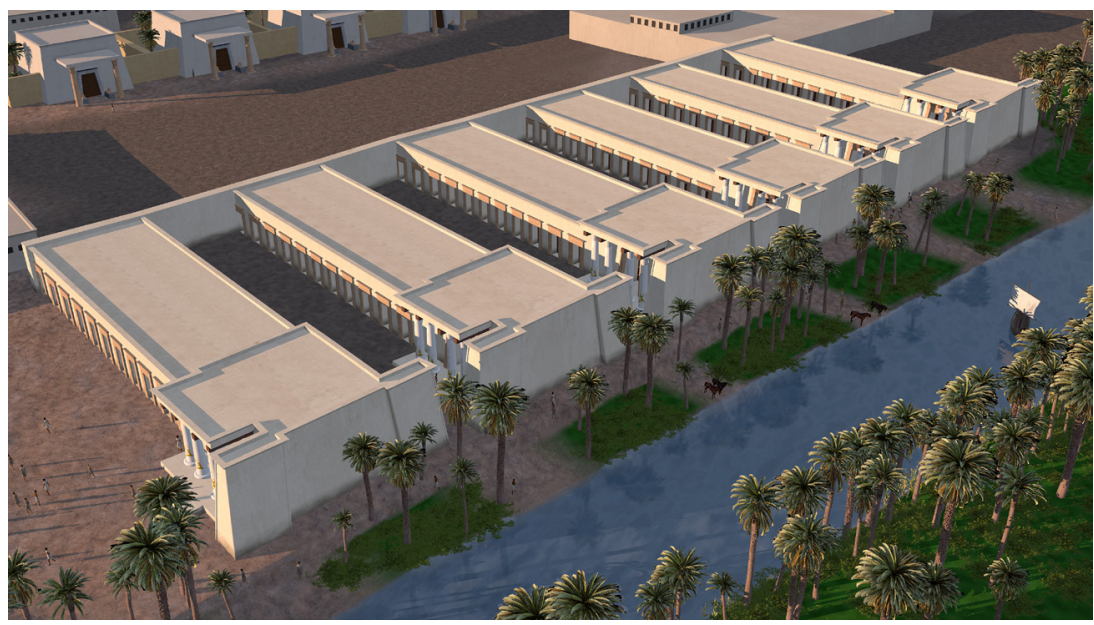

Figure 3: Reconstruction of the royal stables in the city of Pi-Ramesse in the early 13th century вСЕ, 2016. () artefacts-berlin.de.

in existence (like the royal palaces, now probably found where expected, see Franzmeier, forthcoming).

In order to give the audience a way to understand this underlying thought process, the decision was made to present, before showing a whole reconstructed city, the sources used. After introducing the site, a $3 \mathrm{D}$ view shows the empty island in the Nile where Pi-Ramesse was located. On a first layer, the excavated areas of the city are mapped, which comprises only $0.25 \%$ of the whole estimated city area. On a second layer, the extensive geomagnetic prospection is shown, which comprises at least $10 \%$ of the whole area. Only then does the animation show the reconstruction in these introduced parts, areas that owing to the excavation and geomagnetic prospection can be reconstructed to a certain degree of certainty. The image speaks for itself, as only a small fraction of the city area is actually reconstructed (less than $10 \%$, as not all of the magnetic survey detected remains). Only as a last layer, the animation shows a full reconstruction (with flyovers!) of the city of Pi-Ramesse, as we presume it to have been, and then continues in displaying certain details of the city (Figure 3). All steps in the animation are accompanied by explainatory texts showing the museum visitor the sources used and openly discussing the uncertainty of the reconstruction.

The animation is now part of the permanent exhibition at the Roemerund Pelizaeus Museum in Hildesheim, where artefacts of the excavation in Pi-Ramesse are also displayed. Additionally, the animation was presented in another exhibition in 2019 at the Cincinnati Museum Centre in Ohio, USA, titled 'Egypt: The Time of Pharaohs', a touring exhibition through North America. Images of the reconstruction were used in various popular special-interest 
magazines (e.g. Antike Welt 2019; Welt der Wunder 2019). The result of this project is therefore used for scientific as well as popular science communication in various ways.

This example shows what is already in discussion today: thorough documentation, presentation and communication of archaeological reconstructions (Hageneuer 2019). In reconstructing for a broader audience in particular, we as archaeologists need to take on the responsibility of communicating our work correctly without creating an image of the past that is accepted without discussion. In the archaeological community, at least since the theoretical discussions of post-processualism, we are quite aware of not blindly accepting the results as they are presented. We need to bring this critical thinking into the museum as well and engage visitors by enabling them to evaluate the knowledge presented to them.

\section{Challenges of the future}

We can never predict what will happen in the future, but upcoming technologies like virtual or augmented reality are already finding their way into museums today (see Muñoz/Martí in this volume). The same holds true for reconstructions as presented in this chapter (as well as Quick in this volume) or interactive games and apps (Riethus in this volume). As technologies will get cheaper and more easily usable, I am expecting an increase of these technologies inside museums, not to mention the invention of new technologies. The question I am concerned with here, however, is not what technologies to expect (see Ch'ng 2009) but rather to reflect on the future methods of communicating the past in museums to not repeat the mistakes already made.

We should ask ourselves the question: are these new technologies that will improve in hyperrealism, immersion and usability a good way of communicating the past or not? In increasing the realism of reconstructions we also increase their potential for evoking authority and therefore misinformation. This does not necessarily mean we should not create sophisticated reconstructions or pursue the development of virtual environments for archaeology and for archaeological communication, but we have to use guidelines to do so and to communicate them correctly. Guidelines that already exist, like the London Charter (2009) or the Seville Principles (2011) are very useful documents in that regard, but they are in no way binding to archaeological projects or museums.

The responsibility lies therefore with the creators and the contracting clients (e.g. archaeological projects or museums) to invest the extra effort in creating reconstructions following these guidelines and afterwards ensuring that the communication is done in a way which is informing and not misleading the visitor. This is also dependent on the thoughtful selection of available technologies and possible realism in these works. I would also argue that most of the 
time this is even intended by the creating authors, but the responsibility does not end there. As copyright holders of reconstructions, we have the possibility to make sure our visualisations get communicated the right way even in the future. We can for example demand a clear declaration of the image or animation as a 'reconstruction' or 'proposal' when used by third parties. It is more difficult, though, when the copyright does not exist anymore, as in the case of Layard's reconstruction. ${ }^{4}$ In this case, the third party has the responsibility to correct communication, but as experience shows this is not always the case.

In my opinion, the communication of the past is in fact the most important part of our field. The example of Layard shows us that the longevity and authority of these images exist and are not revoked easily. Owing to developments in our field and cheaper technologies, images like these are not restricted to artists or even archaeologists anymore. The creation of hyper-real reconstructions is getter easier year by year and their number will therefore increase. This leads me to the importance of correct documentation and especially communication, as I have shown in my own example. This is of course in need of improvement and the level of showing uncertainty has to get significantly higher. Here, creators and contractors need to take on the responsibility, especially in the future. We already have two guidelines that are concerned with authority (London Charter 2009: 3.3), documentation (London Charter 2009: 4.1-4.12; Seville Principles 2011: 7.1) and communication (Seville Principles 2011: 4.1-4.3), but they are not binding in any way. I would argue that, if contracting clients or funding organisations persist on using these guidelines, the communication of archaeological reconstructions will get more transparent and in fact more communicative, as people outside the reconstruction project will be able to take part on the discussion and interpretation. Museum visitors can get involved in the thinking process instead of absorbing a prepared image in an exhibition and can get a better communicated past in the future.

\section{References}

Adkins, L. (2003). Empires of the Plain: Henry Rawlinson and the Lost Languages of Babylon, New York: Harper.

Antike Welt (2019). Auferstehung der Antike. Archäologische Stätten digital rekonstruiert. Special Issue. Darmstadt: Zabern.

Artefacts (2016). The Reconstruction of Pi-Ramesse. [online] Artefacts. Available at: http://piramesse.artefacts-berlin.de/ [Accessed 16 May 2019].

Aufrère, S., Golvin, J.-C. and Goyon, J.-C. (1991-1997). L'Égypte restituée. 3 volumes. Paris: Errance.

${ }^{4}$ Depending on the country and whether we are talking about a person or a company as the copyright holder, the copyright expires 70-95 years after the death of the creator. 
Bahrani, Z. (2001). History in reverse: Archaeological illustration and the invention of Assyria. In: T. Abusch, P.-A. Beaulieu, J. Huehnergard, P. Machinist, P. Steinkeller and C. Noyes, eds, Historiography in the Cuneiform World: Proceedings of the XLV Rencontre assyriologique international. Bethesda, MD: CDL Press, pp. 15-28.

Bator, S., van Ess, M. and Hageneuer, S. (2013). Visualisierung der Architektur von Uruk. In: N. Crüsemann, M. van Ess, M. Hilgert and B. Salje, eds, Uruk5000 Jahre Megacity. Exhibition Catalogue. Petersburg: Imhof, pp. 365-371.

Buccellati, F. (2015). What might a field archaeologist want from an architectural 3D model? In: M.G. Micale and D. Nadali, eds, How Do We Want the Past to $\mathrm{Be}$ ? On Methods and Instruments of Visualizing Ancient Reality. Piscataway, NJ: Gorgias Press, pp. 157-169.

Ch'ng, E. (2009). Experiential archaeology: Is virtual time travel possible? Journal of Cultural Heritage, 10(4): 458-470.

Der Spiegel (2016). Mesopotamien. Aufbruch in die Zivilisation, Der Spiegel Geschichte 2/2016, Hamburg: Spiegel.

Endruweit, A. (1994). Städtischer Wohnbau in Ägypten. Klimagerechte Lehmarchitektur in Amarna, Berlin.

Faiella, G. (2006). The Technology of Mesopotamia, New York: Rosen.

Franzmeier, H. (forthcoming). Qantir-Pi-Ramesse - Preliminary Report on the 2016 and 2017 seasons (site Q VIII). In: Proceedings of the Sixth Delta Survey Workshop, held at the University of Mansoura, 11-12 April 2019, Special Edition of the Journal of Research, Mansoura University, 2020.

Franzmeier, H. and Hageneuer, S. (2017). From the Nile Delta to Karlsruhe: Or how to present mud bricks in an exhibition. CIPEG Journal, 1: 15-26, DOI: https://doi.org/10.11588/cipeg.2017.1.40326.

Franzmeier, H. and Pusch, E.B. (2016). 'Pi-Ramesse'. In: M. Bauks and K. Koenen, eds, Das wissenschaftliche Bibellexikon im Internet, [online] Available at: http://www.bibelwissenschaft.de/stichwort/32607 [Accessed 16 May 2019].

Golvin, J.-C. (2019). Jean-Claude Golvin. [online] Jean-Claude Golvin. Available at: https://jeanclaudegolvin.com [Accessed 20 May 2019].

Hageneuer, S. (2014). The visualisation of Uruk - First impressions of the first metropolis in the world. In: W. Börner and S. Uhlirz, eds, Proceedings of the 18th International Conference on Cultural Heritage and New Technologies 2013 (CHNT 18, 2013). [pdf] Wien: Museen der Stadt Wien. Available at: https://www.chnt.at/chnt-18-2013-proceedings [Accessed 16 April 2019].

Hageneuer, S. (2016a). The influence of early architectural reconstruction drawings in Near Eastern archaeology. In: R.A. Stucky, ed., Proceedings of the 9th International Congress on the Archaeology of the Ancient Near East, Wiesbaden: Harrassowitz, pp. 359-370.

Hageneuer, S. (2016b). Die virtuelle Rekonstruktion von Pi-Ramesse. In: Badisches Landesmuseum Karlsruhe, ed., Ramses. Göttlicher Herrscher am Nil, Petersburg: Imhof, pp. 268-272. 
Hageneuer, S. (2016c). Archaeological Reconstructions. [online] Smarthistory. Available at: https://smarthistory.org/archaeological-reconstructions [Accessed 9 May 2019].

Hageneuer, S. (2019). 'Without drawing the study of antiquities is lame!' Architektur-Rekonstruktion als wissenschaftliches Tool? In: P. Kuroczynski, M. Pfarr-Harfst and S. Münster, eds, Der Modelle Tugend 2.0, Heidelberg: arthistoricum.net, pp. 203-212.

Lanjouw, T. (2016). Discussing the obvious or defending the contested: Why are we still discussing the 'scientific value' of $3 \mathrm{D}$ applications in archaeology? In: H. Kamermans, W. de Neef, C. Piccoli, A.G. Posluschny and R. Scopigno, eds, The Three Dimensions of Archaeology, Proceedings of the XVII UISPP World Congress (1-7 September 2014, Burgos, Spain), Volume 7/Sessions A4b and A12, Oxford: Archaeopress, pp. 1-11.

Larsen, M.T. (2010). Versunkene Paläste - Wie Europa den Orient entdeckte, Berlin: Osburg.

Layard, A.H. (1849a). Nineveh and Its Remains: With an Account of a Visit to the Chaldean Christians of Kurdistan, and the Yezidis, or Devil-Worshippers; and an Enquiry into the Manners and Arts of the Ancient Assyrians, London: John Murray.

Layard, A.H. (1849b). The Monuments of Nineveh. From Drawings Made on the Spot, London: John Murray.

Layard, A.H. (1853a). Discoveries among the Ruins of Nineveh and Babylon; with Travels in Armenia, Kurdistan and the Desert: Being the Result of a Second Expedition Undertaken for the Trustees of the British Museum, New York: Harper \& Brothers.

Layard, A.H. (1853b). A Second Series of the Monuments of Nineveh, London: John Murray.

London Charter (2009). The London Charter for the Computer-Based Visualisation of Cultural Heritage, Draft 2.1. [pdf] London Charter. Available at: http://www.londoncharter.org/fileadmin/templates/main/ docs/london_charter_2_1_en.pdf [Accessed 18 May 2019].

Micale, M.G. (2010). Designing architecture, building identities. The discovery and use of Mesopotamian features in modern architecture between Orientalism and the definition of contemporary identities. In: P. Matthiae, ed., Proceedings of the 6th International Congress on the Archaeology of the Ancient Near East (Rome, May 5-10 2008), Wiesbaden: Harrassowitz, pp. 93-112.

Parpola, S. and Whiting, R. (1997). Assyria 1995. Proceedings of the 10th Anniversary Symposium of the Neo-Assyrian Text Corpus Project, Helsinki, September 7-11, 1995. Helsinki: Neo-Assyrian Text Corpus Project.

Piggott, A. (1978). Antiquity Depicted: Aspects of Archaeological Illustration, London: Thames and Hudson.

Pusch, E.B. and Herold, A. (2001). 'Piramesse'. In: D.B. Redford, ed., The Oxford Encyclopedia of Ancient Egypt, 3, Oxford: Oxford University Press, pp. 48-50. 
Reade, J. (2008). Nineteenth-century Nimrud: Motivation, orientation, conservation. In: J.E. Curtis, H. McHall, D. Collon and L. al-Gailani Werr, eds, New Light on Nimrud. Proceedings of the Nimrud Conference 11th-13th March 2002, London: British Institute for the Study of Iraq, pp. 1-21.

Seville Principles (2011). The Seville Principles. International Principles of Virtual Archaeology, final draft. [pdf] Seville Principles. Available at: http://smartheritage.com/wp-content/uploads/2015/03/FINAL-DRAFT. pdf [Accessed 18 May 2019].

Simon, J. (1997). Drawing inferences. Visual reconstruction in theory and practice. In: B.L. Molyneaux, ed., Cultural Life of Images. Visual Representation in Archaeology, Abingdon: Routledge, pp. 22-48.

Tietze, C. (2008). Amarna: Lebensräume - Lebensbilder - Weltbilder. Potsdam: Universitätsverlag Potsdam.

Welt der Wunder (2019). Das unglaubliche Leben der Bienen, 19(5), Hamburg: Bauer Media. 